\title{
38. EXCHANGE OF ASTRONOMERS (ÉCHANGE DES ASTRONOMES)
}

(Committee of the Executive Committee)

President: M. G. J. Minnaert.

Vice-President: A. Reiz.

Organizing Commirtee: D. Ja. Martynov, P. M. Routly, J. Sahade, J. P. Wild.

Commission 38 gratefully acknowledges the perfect and efficient cooperation with the General Secretary.

During the three-year period 1-1-1967 to 1-1-1970 the following travel subsidies have been granted:

177. Dr M. Khairy Aly

178. Dr K. C. Freeman

179. Mrs Dr Paris Pishmish

180. Dr F. Roddier

181. Dr M. Hockey

182. Dr P. Raghuveer

183. Dr J. Monaghan

184. Dr J. Hadjidemetriou and

184a. Dr G. Bozis

185. Dr K. Ishida

186. Dr A. Tlamicha

187. Mrs Dr A. Ringuelet-Kaswalder

188. Dr I. Kawaguchi

189. Dr M. J. Rees

190. Dr A. Uesugi

191. Dr J. Kleczek

192. Miss Dr S. Itoh

193. Dr J. Kubota

194. Dr H. Haupt

195. Dr K. A. Hämeen-Anttila

196. Dr F. Bertola

197. Dr Y. Sobouti

198. Dr B. Valní̌ek

199. Dr M. Werner

200. Dr E. P. J. van den Heuvel

201. Dr E. L. J. van Dessel

202. Dr K. K. Sen

203. Dr R. C. Canfield

204. Dr D. P. Gilra

205. Dr P. Koubský

206. Eng. C. Slottje

207. Dr N. A. Doughty

208. Miss Dr E. Dekker

209. Dr F. Pacini

210. Miss Dr Beverley J. Harris

211. Dr P. Koubský

212. Dr J. E. Felten

\author{
Helwan to Herstmonceux (R) \\ Austin to London \\ Mexico to Heidelberg \\ Nice to Tucson (R) \\ Oxford to Santa Cruz (R) \\ Hyderabad to Middletown (R) \\ Cambridge to Santa Cruz (R) \\ Thessaloniki to Manchester (R) \\ Tokyo to Austin (R) \\ Ondřejov to Charlottesville (NRAO) (R) \\ La Plata to Liège ( $R$ ) \\ Pic-du-Midi to Kyoto \\ Cambridge to Pasadena (R) \\ Kyoto to Amherst (R) \\ Ondřejov to Utrecht (R) \\ Kyoto to Meudon \\ Kyoto to Pic-du-Midi \\ Vienna to Haute-Provence (R) \\ Oulu to Meudon (R) \\ Padova to Pasadena \\ Shiraz to Philadelphia (R) \\ Ondřejov to Malta (R) \\ New York to Cambridge (R) \\ Utrecht to Santa Cruz (R) \\ Utrecht to Nice (R) \\ Singapore to Nice $(R)$ \\ Denver to Utrecht (R) \\ Hyderabad to Madison \\ Ondřejov to Haute Provence (R) \\ Utrecht to Nançay (R) \\ New Zealand to Hyderabad (R) \\ Utrecht to Maryland (R) \\ Rome to Ithaca (R) \\ Canberra to Columbus (Ohio) \\ Ondřejov to Utrecht (R) \\ Cambridge to Bombay (R)
}


213. Miss Dr H. Demoulin

214. Dr J. Kubota

215. Mrs M. Querci

216. Mrs E. Ribes

217. Dr I. Fejes

\author{
Paris to Austin (R) \\ Pic-du-Midi to Kyoto \\ Paris to Berkeley (R) \\ Paris to Sydney \\ Budapest to Groningen (R)
}

In agreement with a decision, taken at the Prague meeting of 1967 , the names of the recipients have been mentioned, since the allocation of such a subsidy is considered to be a honour and a distinction. All cases in which roundtrip was paid have been marked by (R). Where this indication is not found, it means that the stay abroad extended over more than one year, or that the return fare was paid from other sources.

The number of subsidies in this period reached 44 (including the subcommission). Since the existence of the commission the numbers appear to increase steadily, though there are statistical fluctuations (see figure 1). In 11 cases the requests had to be refused. In 5 cases the promise of a

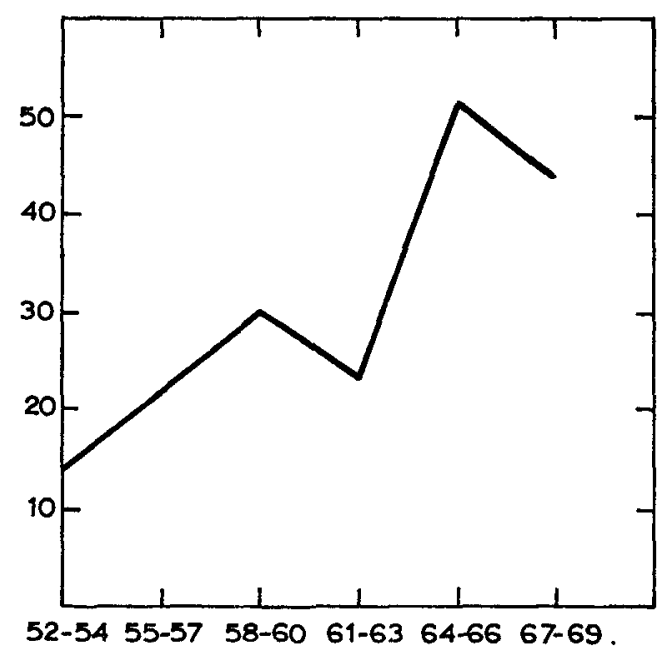

Fig. 1.

subsidy enabled the recipient to accept a fellowship abroad, but afterwards it proved possible to obtain money from other sources and the money was refunded to the IAU.

In the preceding report, we noticed already the increasing percentage of intercontinental travels, which then reached $67 \%$. In this last period this trend persisted; the percentage now amounts to $76 \%$. As a consequence the average amount of a subsidy now amounted to $\$ 562$.-.

Apparently there are nowadays many sources from which travel grants for short trips can be obtained, while the IAU remains one of the few bodies making long-distance journeys possible. The percentage of journeys to the U.S.A. reached $45 \%$.

From the Executive Council a sum of $\$ 22000$.- was gratefully received for the whole of the three years period 1967-70. Our Commission also highly appreciates a generous contribution of $\$ 4000$. - by the ICSU; thanks to that additional subsidy it will probably be possible to satisfy all reasonable applications. During the three years $1966-69$ the grants totalled $\$ 24741$.-, including those of the Sub-commission. For the next period a new IAU subsidy of $\$ 22000$. - will be necessary, assuming that the ICSU will be prepared to grant again a subsidy, comparable to that of the last period.

It should be stressed that the commission has been very economic with the means available. The fares paid correspond to economy class, the peak period was avoided as much as possible and 
preference was given to the cheapest airlines. Notwithstanding the recommendation of the members at the Prague meeting, we have been obliged to keep strictly to our rules and to refuse any subsidy in view of symposia or costs of living. It has not been possible to accumulate a modest reserve fund.

The reports, received from the host observatories and from those who received a grant, show clearly that the visits to foreign observatories have been without exception useful and profitable. Our travel grants have been particularly beneficial during 1969 , when unexpected economic diffculties in some countries made the obtention of official subsidies for scientific travels almost impossible.

It may be useful to remind the members of the IAU that the grants of Commission 38 are available not only for young people, but for astronomers of any age (having reached at least the master's degree). We expect, however, that first of all subsidies from national funds will be applied for.

The Commission tries to work with maximum speed and a minimum of formalities. Nevertheless it appears all the time that applicants are not aware of the information which they are expected to give:

(1) a short indication about their scientific degree and specialization;

(2) the plan for the journey, date of departure, duration of stay abroad, planned investigations;

(3) a letter of the director of the home observatory, expressing his agreement with the travel;

(4) a letter of the director of the host observatory, expressing his agreement with the visit.

(5) When should the money be received and to what address (personal, institute, bank account)?

At the Prague meeting the members of the commission expressed the wish that competent astronomers be sent for some time to countries, not fully participating in the modern development of astronomy, in order to teach there and to direct research. A first attempt in this direction has been made. A circular was sent to 11 countries, of which 3 showed interest in the project and expressed the wish to participate. The Executive Committee transmitted this project to Commission 46, but our commission may have to take care of the travelling expenses.

Information about the activities of Commission 38 was transmitted at their request to: The Dominion Bureau of Statistics (Ottawa), the Secretary of ICSU (Rome), the Grants Register (London), the Consejo Nacional (Buenos Aires).

M. MINNAERT

President of the Commission

\section{REPORT OF SUB-COMMISSION 38}

The sub-commission takes care of applications for travel grants from graduate students, having not yet reached the master's degree.

Five requests have been submitted to sub-commission 38 and two grants conceded, for a total of $\$ 1107.90$.

An amount of $\$ 707.90$ gave the possibility to Mr. B. De (India) to pay his trip Calcutta-Detroit (U.S.A.) in order to enter, in 1968, the graduate school of the University of Michigan. According to Dr. O. Mohler, Chairman of the Astronomy Department, Mr. De has done very well indeed, his marks being without exception in the highest possible category.

Mr. J. D. Finkel (Canada) has received $\$ 400$.-, in 1969, for his roundtrip Montreal-Stockholm in order to work with Professor H. Alfvén. 